\title{
Asian Crisis and Finance Theory
}

Jayanth R. Varma

Indian Institute of Management, Ahmedabad

Reproduced with the permission of Vikalpa, the journal of the Indian Institute of Management, Ahmedabad, in which the paper was first published (October-December 1998, 23(4), 23-34).

(C) Vikalpa (http://www.iimahd.ernet.in/vikalpa). All rights reserved

Abstract
The Asian crisis did not involve generalized financial panic. Stock markets
behaved rationally and the crash in exchange rates is explained by the
presence of credit risk. The crisis highlights the need for better risk
management at the national level focusing less on the size of the external
debt and more on its currency and maturity composition. There should be
more freedom in capital outflows and less reliance on the banking system.
IMF assistance to crisis stricken countries should be in the form of a
currency swap which addresses the root cause of the crisis and subjects the
IMF itself to financial discipline.

The East Asian crisis is above all a financial crisis in the sense that its manifestations and its roots lie in financial markets. The macro-economic issues and the governance issues (corporate, national and supranational governance) are doubtless very important, but these issues have been discussed threadbare in the literature, and, therefore, this paper focuses on the perspectives from financial markets and finance theory.

Specifically, the paper deals with the following: 
- The extent to which the "financial panic" allegedly observed in some of these markets is consistent with efficient and rational markets.

- Applicability of corporate risk management frameworks to the financial risks that East Asian countries (viewing an entire country as a corporate entity) took vis a vis the rest of the world.

- Applicability of the same frameworks to the financial risks that East Asian governments took vis a vis domestic and foreign players.

- The risk management practices of the corporate sector in the East Asian countries

- The role of oligopolistic banking systems as well as restrictions on outward portfolio investment by households in creating excessive financial risk taking at the country level.

- The extent to which credit risk especially "country risk" impedes price discovery in the foreign exchange markets and causes overshooting of the exchange rate.

\section{Financial Panic}

It has been widely observed that the behaviour of financial markets in the region exhibited characteristics of panic which at first sight appear to be contrary to what one would expect in efficient and rational financial markets. Even international agencies noted for their guarded language have abandoned their usual circumspection: "Once the crisis broke, however, markets panicked; exchange rates and equity markets overshot; volatility rose dramatically, with liquidity in some markets drying up" (Bank for International Settlements, 1998, page 117).

Kindleberger's (1996) classic history of financial manias and panics has been widely cited and the herd behaviour of international investors has been much commented upon (for example, Krugman, 1997). In this story, (a) foreign investors rushed into the Asian markets in the early and mid 1990s in a rush of excessive optimism which led to overheated asset markets and booming economies, and (b) equally inexplicably, they were overcome by excessive pessimism in 1997 and rushed out of the region in panic leading to market crashes. If one accepts this story in its extreme form, then we need to turn to crowd psychology and sociology rather than to finance theory to understand the crisis. Other authors while emphasising that financial panic was in evidence have argued that the behaviour while being collectively irrational might have been individually rational (for example, Radelet and Sachs, 1998a and 1998b).

In the case of the Asian crisis, there is one bit of evidence that casts serious doubts about the herding story and the alleged abrupt shift from excessive optimism to excessive pessimism on the part of international investors. This is the behaviour of the stock markets and of foreign investors in the stock markets. Figures 1 and 2 shows the stock market index and the exchange rate in Korea and Thailand. In both countries, the exchange rate 
holds relatively steady till the onset of the crisis and then drops sharply and rapidly. On the other hand, in the stock market we see a gradual decline in prices beginning in early 1996, a year and a half before the crisis. The onset of the crisis is not marked by any corresponding panic in the stock market. In fact, the decline in stock prices post-crisis is fully explained by the devastating impact of the crisis on corporate profitability. What is more by the first quarter of 1998, the stock market in local currency terms is almost back to pre-crisis levels and one is left wondering whether the herd of equity investors is heading in the opposite direction to everybody else.

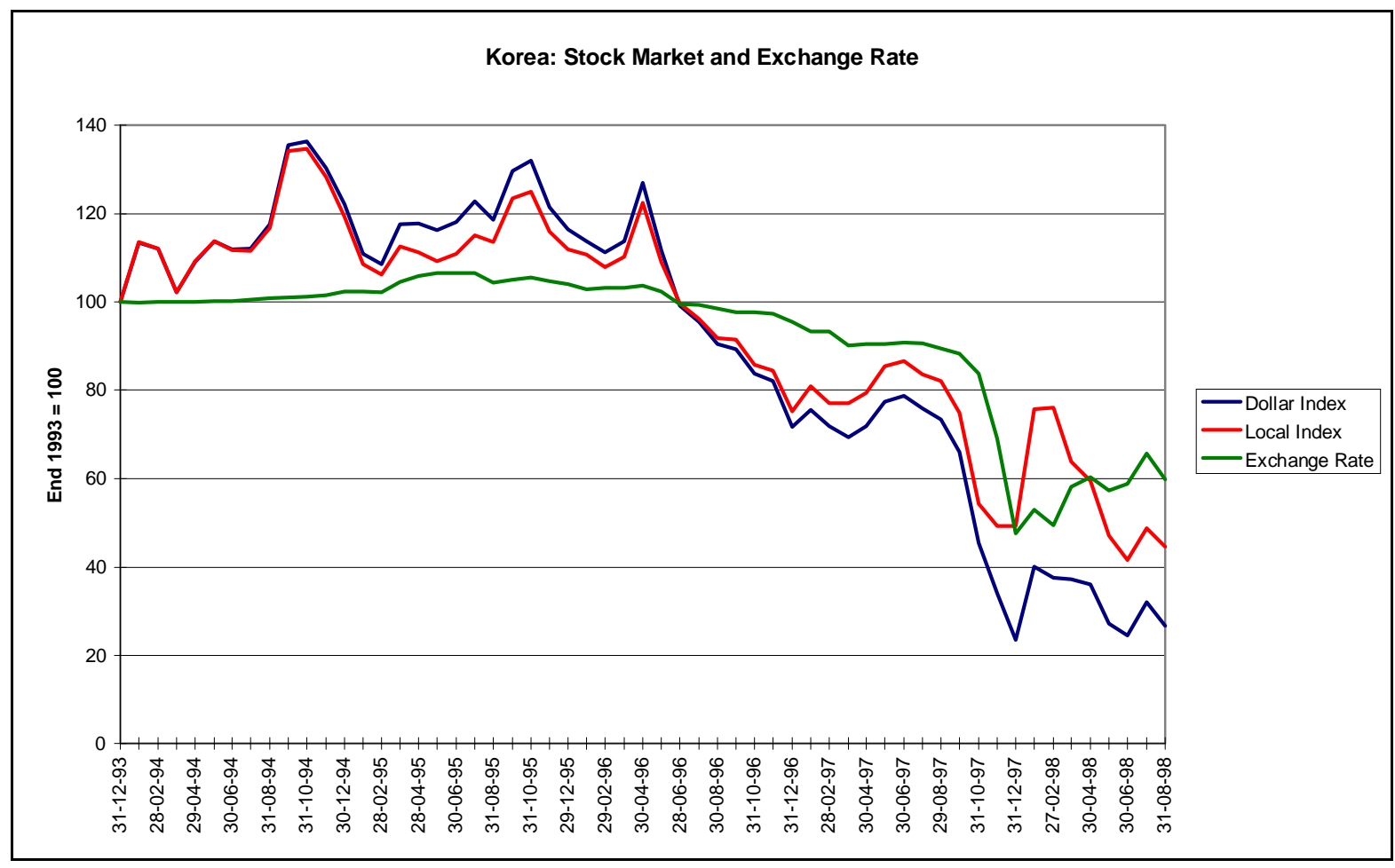

\section{Figure 1}




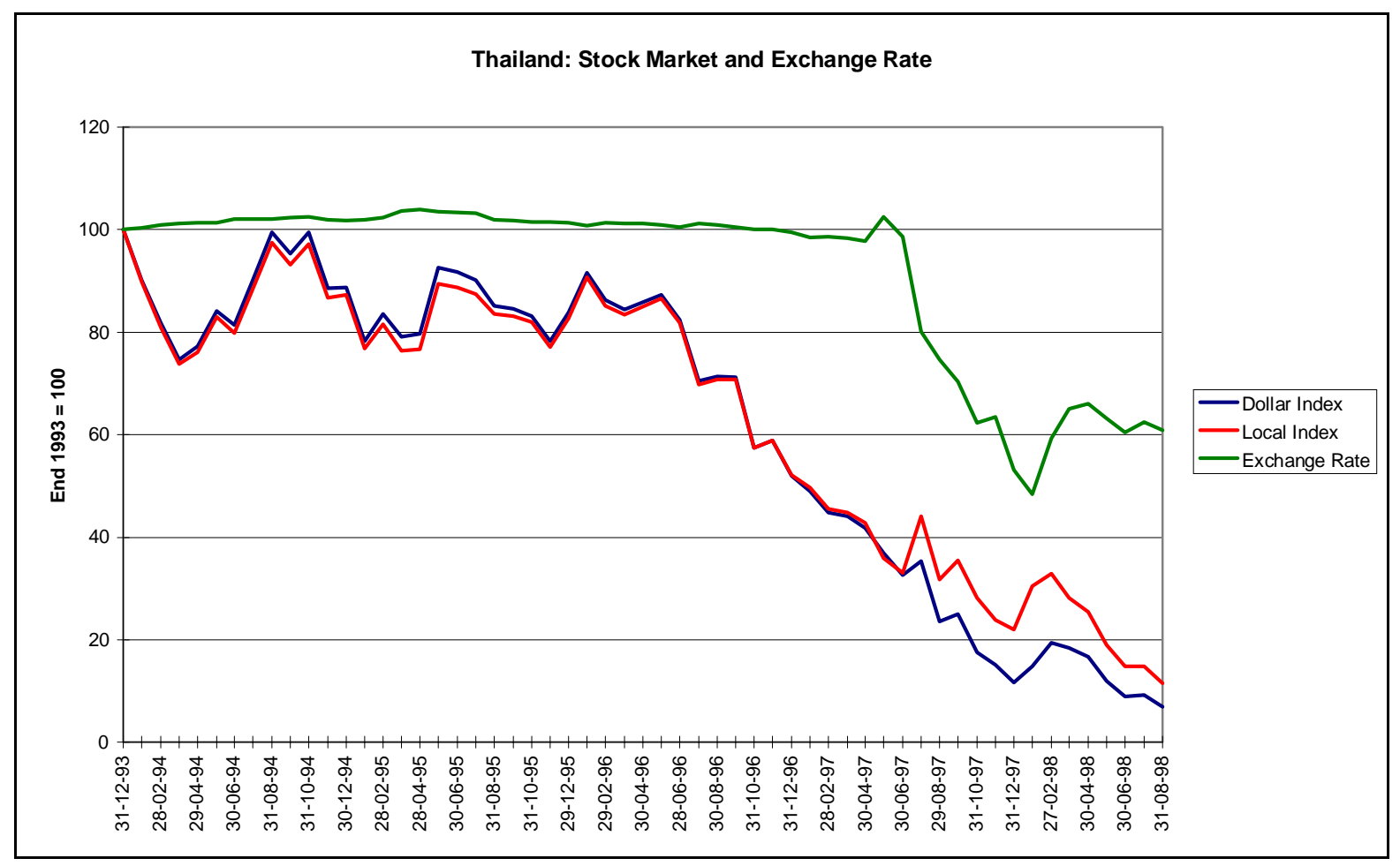

\section{Figure 2}

One might think that the divergent behaviour of stock markets is because of the lower influence of foreign investors in these markets. Maybe foreign investors in the stock markets were herding out of the exits, but the fall in prices was held in check by domestic buyers. This again is rebutted by the evidence. Foreign portfolio investment flows into these countries remained positive through the worst phases of the crisis from mid 1997 to mid 1998. During this year-long period, foreign portfolio investment was positive in every single quarter, while both credit inflows and total financial flows were consistently negative as shown in Table 1 below. In fact, in some quarters during the crisis the portfolio investment inflows is comparable to or even greater than the average quarterly inflows in the pre-crisis year (1996).

\begin{tabular}{|c|c|c|c|c|c|}
\hline & $\begin{array}{c}\text { Average } 1996 \\
\text { Quarterly inflows }\end{array}$ & $\begin{array}{c}1997 \\
\text { 3rd Qtr }\end{array}$ & $\begin{array}{c}1997 \\
\text { 4th Qtr }\end{array}$ & $\begin{array}{c}1998 \\
1 \text { st Qtr }\end{array}$ & $\begin{array}{c}1998 \\
\text { 2nd Qtr }\end{array}$ \\
\hline \multicolumn{6}{|l|}{ Korea } \\
\hline Portfolio investment flows & 3,796 & 5,444 & 428 & 3,871 & 429 \\
\hline Foreign credit flows & 2,771 & $-4,021$ & $-9,999$ & $-4,449$ & 1,200 \\
\hline Total financial flows & 5,824 & 763 & $-9,783$ & -918 & 1,878 \\
\hline \multicolumn{6}{|l|}{ Thailand } \\
\hline Portfolio investment flows & 886 & 2,137 & 278 & 482 & 290 \\
\hline
\end{tabular}




\begin{tabular}{|l|l|r|r|r|r|}
\hline Foreign credit flows & 3,634 & -900 & -1680 & $-2,051$ & $-1,070$ \\
\hline Total financial flows & 4,872 & $-2,117$ & $-4,146$ & $-2,446$ & $-3,032$ \\
\hline
\end{tabular}

Source: IMF, Bank of Korea and Bank of Thailand. Flows are net balance of inflows and outflows. Credit flows refers to the financial account other than direct investment and portfolio investment.

Another dramatic evidence is provided by the Economist Portfolio Poll. The Economist surveys international fund managers every quarter about their global asset allocation what percentage of their funds do they plan to invest in each major stock market in the world. These allocations need to be compared with the share of these markets in the global stock market. If Asia excluding Japan accounts for 4\% of the world's stock market capitalisation, and an investor allocates $4 \%$ of his funds to this region, he is neither bullish nor bearish about this market, but is simply adopting a neutral weightage. If he were bullish, he would allocate significantly more than $4 \%$, while if he is bearish, he would allocate significantly less than $4 \%$. Chart 3 shows the allocation in the Economist Poll to several major markets as a percentage of neutral weights, so that a value above 100 indicates bullishness and a value below 100 indicated bearishness towards that region. We observe than in early 1996, international investors were highly bullish towards Asia excluding Japan - as much as $300 \%$ overweight. As the data indicated significant downturn in these economies in the first quarter of 1996 a year and a half before the crisis), these investors took a more neutral though still slightly bullish posture towards the region. This posture was maintained throughout the crisis. Towards the middle of 1998, the posture once again became highly bullish reflecting the belief that these markets are undervalued in dollar terms. 


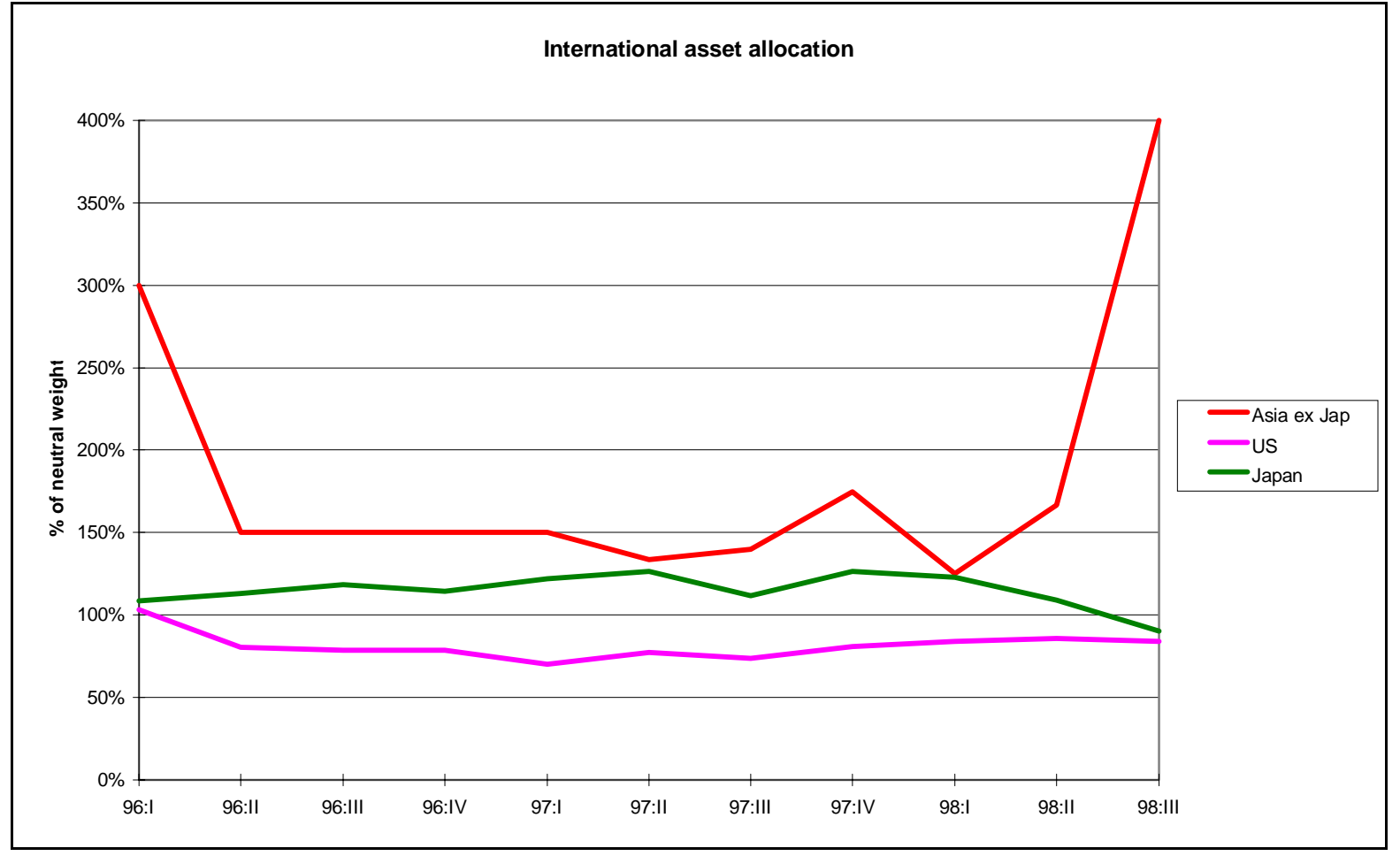

\section{Figure 3}

One of the largest global funds managers (known for its investment philosophy that "The time to buy is when there is blood on the streets even when the blood is your own") launched a Thailand fund at the height of the crisis to take advantage of what was perceived to be attractive opportunities in that country's stock market.

In other words, there is clear evidence that foreign investors were not responding in a panic stricken manner in the stock markets; the panic-like behaviour is seen only in the foreign exchange and credit markets. This suggests that the alleged panic has its origins not in the minds of people (the herd mentality) but in structural characteristics of these markets. It is possible that the observed behaviour is in fact quite rational.

\section{Risk Management at Country Level}

For many purposes, it is convenient and illuminating to view an entire country as a single economic entity by aggregating across all its nationals as is done in national income accounting. We can perform a similar aggregation to take stock of the financial risks being taken by a country as a whole. Countries may not often take such a perspective, nor do foreign lenders necessarily do so. But the notion of country risk does implicitly bring in such a perspective to a limited extent.

Credit rating agencies carry out credit rating of governments (sovereign credit rating) as also of companies. But they usually do stipulate that no borrower within a country can have a higher credit rating than the country's sovereign rating. This implies that the 
sovereign rating is to some extent a risk assessment of the country as a whole and not just of its government. At a purely conceptual level, there should be a country rating distinct from the rating of its government. Most rating agencies do not do that and the sovereign rating is thus an amalgam of these two conceptually distinct risk assessments.

In this paper, financial risk taking at the country level is conceptualised as the net position in various financial markets by all nationals vis a vis the rest of the world. In the case of the East Asian economies, the biggest such positions were in currency and credit markets and arose from the large foreign debt which was denominated in foreign currency and was of short maturity.

\section{Short position in the dollar}

Dollar borrowings by a country's nationals can be regarded as a loan in local currency coupled with a sale by the borrowers to the lenders of forward contracts on the dollar. Implicitly therefore these borrowers (and therefore the country as a whole) had a large short position in dollars (or equivalently a long position in their own currency). These positions were not hedged in any meaningful way (including natural hedges ${ }^{1}$ ). Since total foreign debt net of foreign exchange reserves in these countries was close to half of GDP, the position was similar to a corporate enterprise taking a naked position in the futures markets equal to $50 \%$ of its sales. Any corporate risk manager would regard such a large short position in currency futures as reckless gambling. Put another way an adverse movement of about $20 \%$ in the exchange rate would involve losses to the nation of about $10 \%$ of GDP.

The question arises as to why nations with supposedly conservative governments could end up taking such a large risk. To say that the countries needed foreign capital to finance their investments does not answer the question of the currency denomination of debt. Why is it that in practically all the loans, the borrower ended up taking the currency risk rather than the lender? The risk management literature would suggest that in the case of a small country (and all Asian economies other than Japan are small countries relative to global capital), this risk is best held by lenders because they could diversify the risk easily while for the borrower it represents non diversifiable risk.

The argument that is sometimes heard that foreigners would never lend in local currency at any price is quite absurd. It implies an extreme imperfection in international capital markets which flies in the face of all available evidence. It also conflicts with the well known fact that investors in the stock market are quite willing to bear currency risk given

\footnotetext{
${ }^{1}$ Investment in real assets does not provide a natural hedge since purchasing power parity holds (if at all) only in the very long term and most changes in nominal exchange rates are in fact changes in the real exchange rate. Investments in export oriented industries could provide a natural hedge in certain conditions, but this accounted for only a small fraction of the total investment.
} 
an adequate return expectation. It is certain that foreigners would have been willing to lend in local currency. What is likely however is that domestic borrowers would not have found it attractive to borrow at these rates. Alternatively, by regarding a dollar loan as a local currency loan coupled with the sale of forward cover to the foreigners by the local lenders, we see that the borrowers were offering forward cover at what foreigners considered attractive rates. This is another way of saying that East Asians were speculating on currency rates.

One reason proffered for the alleged unwillingness of foreigners to lend in local currencies is that there is an ever present threat of the loan being wiped out by hyper inflation. This argument has no relevance to East Asian countries with their track record of low inflation in the 1990s. Even otherwise, hyper-inflation risk is not insurmountable as is evident from the success of historically hyper-inflationary Latin American countries, like Mexico, in attracting significant foreign investment in bonds denominated in local currency. Even if hyper-inflation is a serious risk, the problem could be solved by issuing inflation indexed bonds in local currency. Inflation risk is naturally hedged by a borrower undertaking real investments while exchange risk is not (see footnote 1).

It will be argued below that the true reason for the emergence of such large risk taking at the country level lies in government policies that resulted in an oligopolistic banking system and in the capital account controls (in the form of restrictions on outward portfolio investment by households).

\section{Short position on the credit spread}

The fact that a large part of East Asian debt was short term implies that another large financial risk was being taken: a short position on the country's own credit spread. Short term borrowing to finance long term investments amounts to a bet that when the debt comes up for renewal, the country's credit rating would have improved and the debt could be rolled over at a cheaper rate than is implied by the long term borrowing rate. If foreigners are pessimistic about a country's long term creditworthiness, they would be willing to lend long term only at a high interest rate that reflects the default risk. If nationals are optimistic about their own creditworthiness, they would not want to pay this credit spread, but would prefer to borrow short term and roll over the debt in future when (they believe) the credit spread would have declined. Ignoring interest rate risk (discussed below), short term borrowing can be regarded as long term borrowing coupled with a credit derivative position - a short position on the credit spread. If short term debt of $20 \%$ of GDP is incurred to finance a ten year investment, and the credit spread moves by 300 basis points ( 3 percentage points), the loss to the country over the ten year period would be about $6 \%$ of GDP.

This risk was magnified by the fact that much of the borrowing was by highly levered corporate entities whose credit spread could deteriorate very rapidly even without a loss of creditworthiness of the nation itself. The short position was even more dangerous than might appear by regarding it as a position on the credit spread of the country. 


\section{Short position on future interest rates}

Short term borrowing to finance a long term investment also involves a bet on the evolution of interest rates in future. It is in fact a short position on interest rate futures. During the Asian crisis however, risk free US dollar interest rates were generally stable and tended to trend downward. How serious the risk could have been may be seen by looking at the early 1980s when in the first two years of the Reagan era, US dollar LIBOR rates tripled from around 6\% to around 18\%. It was fortunate that the East Asians did not have to contend with a calamity of this kind.

\section{Correlated Risks Aggravate Each Other}

We know that risk positions are more serious when they are positively correlated with each other so that misfortunes tend to strike together rather than singly. A corporate entity with large dollar borrowing finds debt servicing more difficult as the dollar strengthens against the local currency since its assets are all in local currency. As its debt balloons, its net worth would be impaired, its profitability would be eroded, and its debt-equity ratio and its interest coverage ratio would deteriorate very rapidly. In extreme situations, the company could be pushed into bankruptcy. Even if that did not happen, its credit spread would shoot up dramatically as the local currency depreciated. Reduced willingness to lend to nationals would in turn put pressure on the balance of payments and aggravate the depreciation of the currency. Thus the two large risk positions that the nation had built up - a short position on the dollar and a short position on the credit spread of its corporates would aggravate each other and would be much more dangerous in unison than in isolation.

\section{Risk Management at the Government Level}

At the level of the government, it is tempting to argue that there were no significant risk positions. In other words, the apparent risk positions (on the currency and on the credit spread) were taken by private sector participants and not by the government itself. This view however ignores the large contingent liabilities of the government in terms of the implicit guarantees that it extended to the financial sector (and therefore indirectly to the corporate sector).

Risk management in relation to guarantees involves two issues - the prudential monitoring of the guaranteed institution and the scale and size of the guarantees itself.

\section{Monitoring and Supervision}

Risk management by any guarantor would involve monitoring of the guaranteed institution to ensure that that institution is not taking large risks. Inadequacies of prudential supervision are in fact deficiencies in risk management of the guarantor. 
The literature on the East Asian crisis has identified serious deficiencies in the regulation and supervision of the banks and other financial intermediaries. Krugman (1998) has argued that this was in fact at the core of the crisis itself.

\section{Scale and size of the implicit guarantee}

In countries like Korea a long tradition of state-bank-firm co-operation led to implicit guarantees that were imprudently large. The Korean chaebols accounted for a large fraction of GDP, had debt equity ratios in the range of 5:1, and were financed by banks which had implicit sovereign guarantees. In this situation, when the chaebols and banks took risks which were very large in relation to their net worth, the state ended up taking the real risks.

It is possible to argue that the sheer scale of the implicit guarantee was perhaps too large for a prudent state to take up. Yet in a fundamental sense risk taking by the government vis a vis its own citizens is only a transfer of risk within the country and ought not by itself to expose the country to risks. It could even be argued that the taxing power of the state means that it can bear very large risks versus its own citizens in the same way as it can accumulate a large domestic debt to its own citizens. The most important question is what policies allowed the country as a whole to take very large risks.

\section{Risk Management at the Corporate Level}

When we turn to the corporate sector in East Asia, what we observe is financial risk taking on a truly wild scale. Consider for example, one of the largest industrial conglomerates in South East Asia - the Siam Cement group of Thailand. Before the crisis began, this group had a debt-equity ratio of about 3.5:1 and the practically the entire debt (over $\$ 4$ billion) was in the form of unhedged dollar borrowings. On the other hand, the bulk of its revenues and profits came from its domestic operations. Needless to say, the currency depreciation created huge losses on the dollar debt and the group avoided reporting a negative networth only by revaluing its assets. Even before the crisis, it should have been evident to the management that it would not need anything like a currency crisis to put the group into difficulty. The group's pre-crisis situation was such that even a $10 \%$ depreciation of the currency would have caused a pre-tax loss larger than the annual pretax profit of the company. To add to the problems, over $\$ 1$ billion of the foreign debt was short term, and it should have been obvious before the crisis that even a modest currency depreciation would impact the group's creditworthiness and make it difficult to roll over these borrowings at reasonable cost.

Siam Cement is not an isolated example. On the contrary, excessive leverage and imprudently large foreign currency debt was an endemic feature of the corporate sector in East Asia. The large Korean chaebols typically had a debt equity ratio in the range of 5:1, and in many cases, a third or even half of the debt was unhedged dollar debt. Most of the foreign currency borrowings were short term. Compounding the problem for the Koreans was that their profitability (measured by return on net worth) was very low because of 
their aggressive pursuit of market share. This meant that even small adverse developments could push them into the red and impact their creditworthiness seriously. Moreover, they also had large capital expenditure commitments which could be scaled back only at great cost. For example, when the crisis began, the Daewoo group was implementing about 200 investment projects world-wide involving an equity contribution by Daewoo of nearly $\$ 5$ billion - an amount roughly comparable to the combined networth of the entire group. (Including borrowings and the capital brought in by joint venture partners, the total project cost of these projects would have been over five times that amount).

Outright speculation was also quite common as exemplified by the Sekar group in Indonesia. This group had made a mark for itself as a highly profitable processor and exporter of shrimps. Not satisfied with these profits, it decided to speculate in the currency markets. When the crisis began, they had sold call options on the US dollar for an amount equal to about five times its annual sales. If all it wanted to do was to hedge its export receivables, it might have sold options for a couple of months of sales, but its actual position was about 30 times that. It need hardly be added that the group was bankrupted by the crisis and had to be bailed out by the government which was keen to protect the employment provided by the company's shrimp operations.

Even where the foreign currency exposures appeared prudent because of natural hedges, the fine print revealed a different story. This is best exemplified by the Charoen Pokphand (CP) group in Thailand. The company was predominantly in agri-businesses with a significant export orientation. As such, one might have thought that the company had a natural hedge and that dollar borrowing might not be imprudent. However, this argument breaks down when the debt is short term as the company would have to repay the debt immediately while the higher profitability and enhanced competitiveness resulting from the currency depreciation would be realised over a long period. In CP's case, it turned out that many of even the medium term dollar borrowings contained put options that allowed the investor to ask for early repayment. During the crisis, CP struggled to cope with this problem by selling assets to meet some obligations while trying to convince lenders not to exercise the early payment option. Again CP was not alone in facing this difficulty. Many borrowers in East Asia were tormented by a particular kind of put option known as the credit put in which the lender has the right to ask for early repayment if the credit standing of the borrower deteriorates.

The lessons that corporates can learn from the Asian experience is that their vulnerability to crisis depends on:

- The degree of leverage

- The currency composition of debt

- The maturity of the foreign currency debt

- The put options enjoyed by lenders 
- The profitability of current operations

- The amount of committed capital expenditures

It has been pointed out that in many of these dimensions, East Asian corporates were badly placed in comparison to Latin American corporates during their currency crises (Wade, 1998). One of the perplexing questions that arise is why corporates in East Asia took such large financial risks. One explanation that has been offered is that businessmen in these countries were excessively optimistic, and this optimism has even been described as an Asian value. This phenomenon was observed and commented upon long before the crisis. For example, in early 1996, the Economist carried out a survey of business in Asia and reported: "Of the 70 or so people interviewed for this survey, not one named his country's inflation rate, trade deficit, external debt or any other economic indicator as his greatest worry. Business decisions in the region tend to be made on the assumption that rapid economic growth will continue, albeit at a more sedate pace than in the past" (Economist, Business in Asia Survey, March 6, 1996).

This is an important fact, but is not by itself a satisfactory explanation of financial risk taking by East Asian businesses. Like the herd theory of foreign investment, it attempts to find answers in psychology and sociology for problems whose fundamental answers must lie in economics and finance. When we try to understand these fundamental reasons, we shall see that the bad private sector decisions were rooted in bad government policies (Stiglitz, 1998).

\section{Policies that Lead to Financial Risk Taking}

We now turn to the economic and financial policies that led to alarmingly high risk taking at the national level. Risk taking is essentially a trade off between risk and return, and policies can lead to excessive risk taking either by reducing the risk as perceived by the economic agents or by increasing the incentives for them to bear risk.

\section{State as the real risk taker}

While discussing the risk management issues at the governmental level, we concluded that risk taking by the government vis a vis its own citizens is only a transfer of risk and is not by itself dangerous. At a deeper level, however, the financial and economic policies (discussed below) that some East Asian governments followed often made them the only real risk taker in the whole economy. The consequence of these policies is that the only effective risk taking agent in the economy is the state itself. Other economic agents then become complacent about risks as it appears that the state will take care of them if things go wrong. In a closed economy, this matters less as the state as risk taker only distributes risks throughout the society through taxation. In a globalising economy, however, the risks are taken against the rest of the world and not between nationals inter se. The state is not just transferring risks within the economy, but is encouraging speculative risk taking by nationals vis a vis foreigners. 


\section{Excessive reliance on the banking system}

A strong banking network may help boost savings rates and promote development, but, in the process, the savers are encouraged to become depositors who do not take any risks. Risks are taken by banks, and if the banks are poorly supervised and covered by implicit guarantees, the risks are all effectively taken by the state itself. Vibrant equity and bond markets on the other hand could potentially allocate and transfer risks to a wide section of the investing public.

A bloated banking system also induces a high degree of leverage in the business sector. Banks mobilise savings in the form of deposits and these can be deployed only in the form of loans. Thus a high degree of leverage is a necessary concomitant of an unhealthy reliance on the banking system to mobilise savings and allocate capital.

\section{Bail out policies}

Periodic bail out of favoured business houses by the state leads to a situation where the entrepreneur does not really take entrepreneurial risks but looks to the state to protect him from the risks of his own business decisions. A strong state like the Korean state in the sixties and seventies might have been able to extract performance out of the business houses as a quid pro quo for the favours and privileges that it extended to them (see for example, Amsden, 1989). However, it is unlikely that the Korean or any other East Asian state was in such a situation in the 1990s as the quality of governance in several of these countries deteriorated sharply through the eighties and nineties.

Moreover, financial risks often involve bets on factors like exchange rates which are outside the control of individual businessmen. Therefore when things go wrong it is easy for the businessmen to argue that their operating management and performance was excellent and point to clearly identifiable external factors that turned against them. A bail out under these conditions would appear to be a bail out not of an incompetent management but of an unlucky one. This might encourage businessmen to take large bets on things beyond their control and this could explain the Economist's observation about Asian businessmen being unconcerned about inflation rate, trade deficit, external debt or other economic indicators.

A strong benevolent state can thus be thought of as an insurer of last resort where all financial risks (and macro-economic risks) are covered under an implicit insurance policy. The only risks which would not be insurable under such a dispensation would be those related to the operating management of the company. Under a less strong state, the patronage of the state assumes the form of crony capitalism in which even management risks are covered by the state's implicit insurance policy.

\section{Oligopolistic banking system}

Apart from removing the penalties for taking financial risks, the East Asian states might also have created positive incentives for businesses to bear financial risk. Many of the East 
Asian countries had oligopolistic banking systems which were characterised by a large spread between the deposit and lending rates. The banking system did not also have to compete with a well developed bond market. Many corporate borrowers therefore faced domestic borrowing costs which were higher than what they would have been with a competitive banking system. They stood to gain by borrowing from the more competitive international syndicated loan market as well as the deeper and more liquid international bond market. In the process, they assumed large foreign exchange risks.

\section{Restrictions on outward capital flows}

It is interesting to note that the 1990s saw large scale relaxation of restrictions on the business sector in East Asia in terms of inward credit flows, inward portfolio investment (to some extent) and outward direct investment. When one looks at this more deeply, all of these represented concessions to the business lobby, and aggravated financial risk taking by the business sector.

On the other hand, outward portfolio flows by households were strongly regulated in all these countries. An oligopolistic banking system and a poorly developed bond market would normally create incentives for households to seek investment avenues abroad in search of higher returns. Had such capital outflows been permitted, households would conceivably have built up substantial foreign assets through domestic and foreign mutual funds as well as foreign banks. This would have been beneficial in terms of preventing the artificial overvaluation of the currency that occurred in many countries. Moreover, the long dollar positions so created would have partly compensated for the short dollar positions of the corporate and financial sectors. The nation as a whole would have had a more balanced position on the currency and would not have been so badly exposed to a currency crisis.

\section{G-7 Banking Systems}

While this paper has so far focused on East Asian policies that encouraged risk taking, we must not forget that the G-7 countries also provided implicit guarantees to their banks and thereby distorted global financial flows. The ritualised manner in which capital adequacy is measured by BIS norms may also have encouraged G-7 banks to make dollar denominated loans more readily than local currency denominated loans. In fact, global capital flows during the early and mid 1990s looks very much like a game of smoke and mirrors - Asian economies were buoyed up by lending by G-7 banks who were propped up by the implicit sovereign guarantees of their governments whose fiscal deficits in turn were partly financed by the Asian countries through their huge holding of foreign exchange reserves. Much of what has been said above on the excessive reliance on banking systems in Asian economies applies to the G-7 economies as well. 


\section{Behaviour of Foreign Exchange Markets}

One important element in the Asian crisis was the steep fall in the currency to levels which were widely seen as undervalued on any fundamental basis. It is this sharp overshooting that has been widely interpreted as a case of financial panic. Earlier in this paper, it was argued that financial panic is not a reasonable explanation of what happened in these markets. An alternative explanation of the overshooting of the exchange rate is therefore important.

\section{Credit Risk in Foreign Exchange Markets}

The key to understanding this is the simple fact that it is impossible to take any position in a currency without borrowing/lending in that currency. This fact underlies the use of interest rates to defend a currency. The East Asian countries themselves used high domestic interest rates to shore up their currencies during the crisis. The high interest rate makes it more expensive to go short on the currency because it is impossible to short a currency without borrowing it (explicitly or implicitly in the forward market). Apart from interest rates, selective credit controls can also be used in the same effect. During the initial months of the crisis, Thailand did have partial success in defending the baht by making it difficult for foreigners to borrow baht. In the process, they created a sharp separation between the offshore and onshore baht markets which was abolished in 1998 . In the seventies, it was common for countries like Germany and Switzerland to act in the opposite direction - they often made it very difficult for foreigners to open German marks or Swiss Franc deposit accounts in their respective countries and often made interest rates negative on such deposits - to prevent their currencies from appreciating.

All this is well known, but the interesting twist in the East Asian crisis is that lending is inseparable from credit risk. It is impossible to go long on the Korean won without lending in won, and this is impossible without taking a credit exposure on that counterparty. Typically, in a foreign exchange market, the best credit risks are the central bank or the government. A won deposit account (or forward contract trade) with a large Korean bank would essentially be a credit exposure on the Bank of Korea under the assumption of an implicit central bank guarantee for all large banks. Buying a treasury bill instead would be a credit exposure to the government itself. But the situation that could and probably did arise in Korea and elsewhere was that the central bank or the government itself was not regarded as an acceptable credit risk.

The difficulties are even more serious for the person who believes that the currency is undervalued but is confident about its appreciation only in the long term. Such a person would not be willing to buy the currency forward for short maturities. The only effective way for this person to take a long position on the won would be to buy long term won denominated bonds. The best credit risks would be the bonds of the Korean government itself, but these would not have been acceptable credit risks for the investors concerned.

The position is the same for existing lenders. The credit risk would cause them to refuse rollover of loans and to take the money back. They thus end up creating selling pressure 
on the currency even if they have no views on the currency at all or even if they believed the currency to be undervalued.

These difficulties arise due to the institutional structure of the forward markets in foreign exchange. Unlike in the stock exchanges and derivatives exchanges there are no risk containment measures like initial margins and mark-to-market systems. Instead these markets have been bank dominated markets and the major risk containment has been the implicit guarantee of the central bank itself. Thus these markets cannot survive an erosion of confidence in the central bank itself. The closest parallel to that would be a futures exchange in which the clearing house itself is under a threat of bankruptcy.

In theory, an offshore forward market run by large G-7 banks could deal with this problem. In practice, setting up such a market under crisis conditions is impossible. Moreover, even where non deliverable forward markets did exist, they became decoupled from the onshore markets because of exchange controls. Under crisis conditions, an offshore market is not an adequate substitute for the onshore market.

The only immediate solution would have been for the IMF itself to guarantee the credit risk as discussed later in this paper.

\section{Unwinding of levered positions}

Quite apart from the credit risk problem that causes the exchange rate to overshoot, it must be recognized that the unwinding of any large loss making position would cause a large change in prices. Some part of the steep fall in Asian currency markets was therefore no different in nature from the sharp price changes that are observed when hedge funds are forced to unwind their loss making positions. The argument is fairly straightforward. Where investors disagree about the correct price of any asset, the market price reflects the aggregation of these individual beliefs. This aggregation is obviously wealth (or size) weighted in some sense; the views of a large investor matter more for the market price. When some large investors held large levered positions, they would have had a very substantial weight in the aggregation process of arriving at market prices. Now if these positions become loss making bankrupting these investors forcing the liquidation of their positions, the weights in the aggregation process become very different and the equilibrium price itself comes down very sharply even in the absence of panic. The price will have to come down to the reservation price of less bullish investors who now have to hold the assets being liquidated.

In the Asian crisis, the situation was that the short dollar positions were being held mainly by domestic corporate and financial intermediaries. As the depreciating currency pushed them into bankruptcy, the effect was that suddenly the currency had to fall to the reservation price of foreigners. This by itself would have been a steep fall in the exchange rate. This was further exacerbated by the fact that foreign investors could not take long positions because of credit risk. In such a situation, the bottom can drop out of the market even if all market participants behave rationally. 


\section{Conclusions and recommendations}

This analysis leads to a very different set of recommendations and conclusions than what one commonly sees in the literature on the Asian crisis. These are discussed below.

\section{An alternative financial strategy for the IMF}

Under its current policies, the IMF package simply gives more foreign exchange loans to the country, and the country's foreign currency exposure does not decline. As a country, say Thailand, draws down the IMF money to pay a private lender, it ends up owing dollars to the IMF instead of to the private lender. This does not get rid of the dollar liability; at best Thailand ends up with a better maturity profile.

Instead, the IMF could give a loan to Thailand denominated in Thai baht and, after a reasonable time, swap this baht asset for dollars in the foreign exchange (swap) market. Those global investors who think that the baht is undervalued would be happy to take this swap since their counterparty would be the IMF itself. They do not have to take any credit exposure on the Thai government or its central bank. The main obstacle identified in this paper to the smooth functioning of the foreign exchange markets during crisis would be eliminated. Such a process would quickly restore balance to the foreign exchange market and prevent excessive overshooting.

The IMF itself would only end up with a credit exposure to Thailand and not a currency exposure. What is more, the IMF would not even need funds on as large a scale as it does now. Once all the swaps are done, the IMF would have only an off balance sheet liability. It would need funds only for the short period for which it "warehouses" the swap. The country would also benefit enormously because the foreign exchange risk previously borne by it is now transferred to global investors.

This process has the further benefit of alleviating the governance problems which plague the IMF today. In the proposed system, the IMF would have the correct incentives to assess the situation accurately, prescribe correct remedies, and price its local currency loan correctly. If it does not do so, it would suffer losses when it tries to effect the offsetting swap in the global market. There is thus an immediate and clear feedback to the IMF of the efficacy of its policy recommendations. If indeed the markets are in a state of irrational panic, and IMF is able to take a more rational view, it would stand to make large gains when it finally enters the swap market after the panic is over. If instead it was the IMF that was excessively rosy, it would stand to make large losses. The IMF which is currently perceived to lack accountability would be accountable to the sternest of task masters - the financial markets.

The IMF often has to operates in hyper inflationary economies. In these cases, it could make the loan in inflation indexed local currency to prevent the moral hazard that the government might try to inflate away the debt. 


\section{Risk management at the national level}

This study leads to the conclusion that governments should worry about the risk positions that the nation as a whole is taking vis a vis the rest of the world. They should also worry about their own risk management, but the risk management at the national level is far more important. Risk management must always keep in mind that "the economic and financial world is a highly uncertain world in which perceptions of liquidity risk, market risk and credit risk can interact to produce multiplicative effects" (Bank for International Settlements, 1998, page 164).

\section{Limits on Foreign Exchange Exposure}

Contrary to much of the post crisis writing that argues for reduced dependence on foreign borrowing, the emphasis in this paper is on limiting the foreign exchange exposure that the nation takes. Large amounts of foreign borrowing are fine so long as the borrowing is in local currency or are balanced by equally large foreign assets accumulated by the household sector or by mutual funds acting on their behalf.

\section{Freer Capital Account Convertibility}

Capital account convertibility is often seen as the villain of the piece. Even the IMF which used to be one of the votaries of a free capital account has begun to argue that "One lesson ... from the crisis was that countries had to prepare carefully for the liberalisation of the capital transactions to enjoy the benefits of access to global markets while reducing the risks of disruption" (International Monetary Fund, 1998, page 27). This paper argues the opposite. It is asymmetric opening up of capital account inflows with inadequate opening up of outflows that is dangerous. Freeing up of capital outflows for households would encourage nationals to accumulate foreign assets abroad and this long dollar position would balance the short dollar position taken by the corporate sector. Quite apart from its risk management benefits, such liberalisation would provide relief to the household sector from oligopolistic and inefficient banking systems.

\section{Short term borrowing}

This paper agrees with the literature in identifying short term debt as a major problem. But the reason why it is dangerous is that it is a speculative position on the credit spread. As such, the correct policy recommendation would be that short term foreign borrowing should be limited to entities with high and stable credit ratings. If other risk management practices are sound, the creditworthiness of the country itself is likely to be stable and the risks involved in a position on the credit spread are not serious. The short term borrowing becomes problematic when coupled with other sources of fragility. 


\section{References}

Amsden, A. (1989), Asia's Next Giant: South Korea and Late Industrialization, New York, Oxford University Press.

Bank for International Settlements (1998), Annual Report 1998, Basle.

International Monetary Fund (1998), Annual Report 1998, Washington.

Kindleberger, C. P. (1996). Manias, Panics, and Crashes: A History of Financial Crises, Third Edition, New York, John Wiley and Sons.

Krugman, P. (1997), "Seven Habits of Highly Deficient Investors", Fortune, December 29, 1997.

Krugman, P. (1998), What Happened to Asia?, http://web.mit.edu/krugman/www/DISINTER.html

Radelet, S. and Sachs, J. (1998a), The Onset of the East Asian Financial Crisis, Harvard Institute for International Development (http://www.hiid.harvard.edu/pub/other/eaonset2.pdf)

Radelet, S. and Sachs, J. (1998b), The East Asian Financial Crisis: Diagnosis, Remedies, Prospects, Harvard Institute for International Development. (http://www.hiid.harvard.edu/pub/other/bpeasia2.pdf)

Stiglitz, J. S. (1998), “Bad Private Sector Decisions”, Wall Street Journal, February 4, 1998.

Wade R. and Veneroso, F. (1998), The Asian Financial Crisis: The Unrecognized Risk of the IMF's Asia Package (circulated by email). 